This item was submitted to Loughborough's Research Repository by the author.

Items in Figshare are protected by copyright, with all rights reserved, unless otherwise indicated.

\title{
Sociological perspectives on the economic geography of projects: The case of project-based working in the creative industries
}

PLEASE CITE THE PUBLISHED VERSION

http://dx.doi.org/10.1111/gec3.12002

PUBLISHER

(c) Wiley

VERSION

AM (Accepted Manuscript)

\section{PUBLISHER STATEMENT}

This work is made available according to the conditions of the Creative Commons Attribution-NonCommercialNoDerivatives 4.0 International (CC BY-NC-ND 4.0) licence. Full details of this licence are available at: https://creativecommons.org/licenses/by-nc-nd/4.0/

\section{LICENCE}

CC BY-NC-ND 4.0

\section{REPOSITORY RECORD}

Watson, Allan. 2019. "Sociological Perspectives on the Economic Geography of Projects: The Case of Projectbased Working in the Creative Industries". figshare. https://hdl.handle.net/2134/21412. 
Sociological perspectives on the economic geography of projects: the case of project-based working in the creative industries

\author{
Allan Watson \\ Department of Geography \\ Staffordshire University \\ Leek Road \\ Stoke-on-Trent \\ Staffordshire ST4 2DF \\ UK \\ a.watson@staffs.ac.uk
}




\section{Sociological perspectives on the economic geography of projects: the case of project-based working in the creative industries}

\section{Abstract}

In recent years, there has been a growing concern in economic geography with the organisational practices of project-based working, involving a multiplicity of organisational and personal social networks. Paralleling this debate has been a growing academic interest in the cultural economy and the conditions of creative work, itself characterized by project-based working. Cultural and creative workers are argued to symbolise contemporary transformations of work more than any other group of workers. However, despite this being a wide trans-disciplinary area of enquiry, little economic geography literature has engaged explicitly with perspectives being developed in other disciplines, in particular sociology and cultural and media studies, on the experience and conditions of work in projectbased industries. In this paper I argue for the incorporation of sociological perspectives into our analyses of projects, in order to address the lack of attention to the sociological, political and cultural issues of work. Such an approach, I suggest, can contribute to the economic geography of projects in three ways; first it moves beyond structural analyses to allow for an understanding of the importance of agency in project work; second it allows us to move on from firm-level analyses to develop an understanding of the complex social networks involved in projectbased working; and finally it moves on from research at the meso-level on interand intra-firm networks to provide micro-level analyses of project work. 


\section{Introduction}

Over recent years there has been an increased interest amongst economic geographers in the organisational practices of project-based working. Projects represent particular forms of temporal and spatial co-ordination between different actors. These actors collaborate over a pre-determined period in order to complete a pre-specified and usually complex task (Lundin \& Söderholm 1995). The complexity of the task necessitates the coordination of multidisciplinary skills that it is not economically efficient to bring together on a permanent basis (Lorenzen \& Frederiksen 2005), and the task must often be completed under severe time constraints (Hobday 2000; Staber 2004). It is argued that projects represent an efficient form of organisation for mastering tasks of high complexity, stimulating creativity and individual learning and adapting to changing economic and institutional conditions (see for example: von Bernuth \& Bathelt 2007; Hobday 2000; cf. Davenport 2006). Project-based work is becoming increasingly widespread as an organisational form and many economic sectors are now following a trajectory that is resulting in an increase in freelance work, temporary jobs, self-employment, and greater job mobility (Jones 1996; Defillipi \& Arthur 1998; Ekstedt et al. 1999; Gann \& Salter 2000; Blair et al. 2001).

For Grabher (2002a), the integrity of the firm as the basic analytical unit of the economic process is being increasingly undercut by organisational practices that are built around projects involving a multiplicity of organisational and personal networks (see also: DeFillipi and Arthur 1998; Lundin and Midler 1998; von 
Bernuth and Bathelt 2007). In economic geography firms have been considered the elementary units of collective commercial agency, and as a consequence have been largely unproblematised as unitary and coherent actors (Yeung 2003; Maskell 2001; Taylor and Asheim 2001). As Grabher (2004a) suggests, at the meso-level economic geography research on networks has largely been focused at an interorganizational level. It is typical of much of this research that overlapping social networks, and the individual actors that constitute them, are uncritically subsumed into inter-firm networks. Ettlinger (2003) argues that this top-down strategy excludes the people involved in the daily practices of work, and leads to an 'ecological fallacy' whereby it is presumed that what holds for firms in networks also holds for individual actors. For Yeung the 'firm' is a "messy constellation of multiple identities, contestation of power, and shifting representations" (2005: 451) and, as such, monolithic 'black box' conceptions of this crucial analytical category need to be revised. A relational perspective on economic geography explicitly draws attention to the importance of economic actors and how they associate and interact in space (see Bathelt and Glückler 2003), with more recent work also highlighting the importance of latency and dissociation in relational networks (see Vorley et al. 2012). Thus from a relational perspective it is social actors, rather than the firm as an abstract entity, that have become the key analytical focus (Ettlinger 2003; Yeung 2005). However, despite such arguments, firms still retain an ontological and epistemological primacy in economic geography.

In research emerging from sociology and cultural studies on the nature of project-based work in the creative industries, however, the firm does not have this primacy. In these disciplines there has been a 'turn to labour' that is a result of the 
recognition of the growing importance of work in contemporary lifestyles and a response to neo-liberal management ideologies (Holt and Lapenta 2010). For some time, sociologists and cultural studies scholars have been producing productivist critiques of the cultural economy that focus on the politics of cultural work and emphasise the exploitative nature of capital and the demands placed on workers by the commercial imperatives of the firm (see, for example: Ross 2003; Banks 2007; Banks \& Hesmondhalgh 2009). More recently, these productivist critiques have developed into more nuanced, qualitative accounts which recognise the complexities of experiences of cultural work (see, in particular, Gill \& Pratt 2008, and Hesmondhalgh \& Baker 2010) and the de-differentiation of paid, voluntary and 'free' labour (see for example McRobbie 2002; Terranova 2004).

A wide range of geographical literature focusing on the creative industries has challenged the primacy of the firm as the sole analytical unit. Much of this literature has, for example, emphasised social aspects of production and the role of individual actors in the production process (see, for example: Bathelt, 2002, 2005; Pratt 2000, 2002; Power \& Hallencreutz 2002; Power \& Jansson 2004; Turok, 2003; Watson 2008), while another strand of this literature has examined the political economy of production networks (see, for example: Coe, 2001; Coe and Johns, 2003; Johns, 2006, 2010; Yoon and Malecki, 2009). However, little geographical work has penetrated down to the level of examining the sociological, political and cultural issues and practices of work within these industries. Notable exceptions in this regard include Susan Christopherson's work on the labour market in the new media (Christopherson 2002, 2004) and the US motion picture industry (Christopherson \& Storper, 1989); Andy Pratt on precarious working in the 
creative industries (Gill and Pratt, 2008); as well as Glen Norcliffe (Eberts and Norcliffe, 1998; Norcliffe and Rendance, 2003) on artisan production in the computer animation and comic book production industries.

In response to the lack of attention to these issues, in this paper I argue for the incorporation of sociological perspectives into our analyses of projects. Although in itself not something new, such a framework is something that has been rarely explored by economic geographers. Such an approach has some overlap, for example, with production network approaches, in that it shares concerns with how value is created, enhanced and captured in production networks and how power is created and maintained (Johns 2006). However, it is also distinct from such approaches in that it is far less concerned with issues of territorial embeddedness, regional development and organisational structures, and far more concerned with how issues of work, value creation and power, play out at the level of the individual. It is an approach that aims to complement current economic geographical research on projects, which draws on notions of organisational structure, nature, form and efficiency, by allowing for the development of more nuanced understandings of the neo-liberalisation of work in project-based industries.

\section{The economic geography of projects}

A significant body of economic geography literature has emerged on projectbased economic organisation, arguably the most important contributor to which has been Gernot Grabher. Grabher (2001b, 2002a) identifies a number of paradoxes 
about project-working that challenge some of the key assumptions that have been pervasive in economic geography. First, projects often entail high-risk and highstake outcomes, yet they seem to lack the normative structures and institutional safeguards that minimise the likelihood of failure. Second, projects depend on an elaborate body of collective knowledge and diverse skills, yet there is mostly insufficient time to clarify abilities and competencies of members in order to plan for a detailed division of labour. Finally, there is no time in project work to engage in the usual forms of confidence and trust-building activities that contribute to the development of trust in more traditional, enduring forms of organisation (see also: Staber 2004; Koskinen et al. 2003).

Grabher argues that these paradoxes can be resolved, in part, by extending the view from the isolated project to the societal context in which projects operate. He argues that networks, localities, and institutions feed essential sources of information, legitimation, and trust that provide the very preconditions for the 'projectification' (Midler 1995) of economic organisation. First, with regards to networks, Graber argues that projects operate in a milieu of recurrent collaboration that, after several project cycles, provides a pool of resources and 'gels' talent into latent networks, forming "a latent reservoir of resources to be utilized when needed" (Staber 2004 - 32). Projects, he argues, are the realisation of a potential that is generated by the practice of drawing on a network of social contacts, ties, and core members of successful previous projects to serve on successor projects (see also Jones 1996; Defillipi \& Arthur 1998). As such, economic action becomes embedded in networks which are socially constructed (see Crewe 1996). Possibilities to set up quickly a new project team for a specific task largely depend 
on existing inter-personal networks and access to a latent pool of specialists (von Bernuth \& Bathelt 2007). This helps to reunite actors and reassign resources in the face of changing demands (Staber 2004). Interpersonal rather than inter-firm relations bind networks together and become the conduit for project assembly and operation (Ekinsmyth 2002). Chains of repeated cooperation are held together or cut off, Grabher argues, by the reputation that members gain or lose in previous collaborations. 'Know-who' plays an important role in selecting partners for a project team (Christopherson 2002; Gann \& Salter 2000). Thus "project business is reputation business" (Grabher 2001b - 1329).

Secondly, with regards to localities, Grabher argues that repeated project collaboration quite often, although not necessarily, takes place in densely-knit clusters. The co-location of project partners allows for significant savings on transaction costs, such as search costs, and the costs of supervising and enforcing contractual agreements. But perhaps more importantly, co-location provides favourable preconditions for rapid face-to-face interaction and local 'buzz' (see Storper \& Venables 2004; Watson 2008). As Grabher argues, the tighter the project schedule and the less a clear separation of specific tasks can be preprogrammed, the stronger the imperatives for face-to-face interaction. Moreover, spatial proximity facilitates the continuous 'monitoring' of the relevant pool of resources, potential collaborators, and new trends (see also Bathelt 2005). However, Grabher suggests that while notions of 'monitoring' and 'scanning' suggest intentional and strategic activity, this may not be the case. Rather, he suggests that actors located in the pool are subject to 'noise', such that instead of deliberately 'scanning' their environment in search of a specific piece of 
information, they are surrounded by a concoction of rumours, impressions, recommendations and strategic misinformation. Co-location facilitates the emergence of 'interpretive communities' (see Brown \& Duguid 1991) that filter and transform this 'noise' into meaningful signals. These processes of 'negotiated meaning', Grabher argues, tie project clusters together. It is also argued that agglomeration of potential project collaborators provides favourable pre-conditions for hanging out in local 'communities of practice' (Wenger 1988). Communities of practice serve as a sort of informal educational system for disseminating knowledge that goes far beyond the technical competences of the trade and also includes codes of conduct and the 'habitus' (Bourdieu 1984) of the community of practice. These communities develop a set of acquired schemata, sensibilities, dispositions, taste, values, lifestyles and 'ways of doing' (McDowell 1997) that are particular to a group of workers. Learning, Grabher argues, is therefore not simply about the transfer of knowledge, but rather about becoming an 'insider'. It is important, however, to note that these communities of practice are not necessarily geographically constrained: Asheim (2002), for example, argues that the continued importance of localised learning is being challenged by the increasing importance of temporary project working. Personal and professional networks are increasingly spanning the globe, resulting in geographically far-flung project collaborations. Cole (2008) for example highlights how the spatially-extended project ecology of the European animation industry is a notable exception to the tendency for cultural industries to cluster in tight agglomerations.

Finally, with regards to institutions, Grabher argues that projects are embedded in an institutional context of normative structures that provide the very 
basis for co-ordinating complex tasks, and that facilitate the emergence of what Meyerson et al. (1996) define as 'swift trust'. This is a category-driven trust where actors can deal with one another more as roles than as individuals. Consequently, expectations are more standardised and stable; they are defined more in terms of tasks than personalities; and they are shaped by conventions, norms and regulations that accelerate and stabilise the formation of inter-personal and interorganisational perceptions and expectations. Other forms of institutional interdependence exist between the character and content of project work and the politically-crafted rules which Christopherson (2002) argues determine the grounds for competition in an economy; the degree to which labour is flexible in response to changing market conditions; and the ability of firms to move into, and out of, potential areas of capital accumulation.

Grabher $(2001 \mathrm{a}, 2002 \mathrm{~b})$ argues that as projects are repeated over time, 'project ecologies' may emerge, involving a range of different firms and organisations, individual actors, technologies, spaces and places. Here project ecologies are understood as involving the interdependencies between a particular project and the firms, personal relations, localities and corporate networks from which these projects mobilise essential sources. These ecologies, he argues, will form the backdrop to every subsequent project initiated, as new projects find their participants in the ecology. Thus, as DeFillippi and Arthur (1998) assert, fluid project working challenges the idea of core competencies existing as internal resources. Rather, in projects, essential resources and competencies are drawn into firms on a project-by-project basis, involving interactions occurring across networks that cross-cut formal organisation as well as informal organisations 
(Ettlinger 2003). As such, activities in temporary projects are dominated by individual knowledge embodied in highly mobile project members. As these embodied creative knowledges are for sale on the labour market, any competitor can potentially draw on competencies, and individual skills are transferred between projects as project members typically collaborate simultaneously with a wide range of firms. Thus core competencies in project ecologies, rather than internal resources in a strict sense, are "abilities to mobilise resources in a highly fluid organisational ecology... to recombine internal and external resources" (Grabher 2002b - 1915). In 'market-based' projects (see for example Lorenzen \& Frederiksen 2005 on the music industry) participating skill holders are employed in different firms or may be freelancers. Such projects transcend the boundaries of firms and allow firms to draw on relevant knowledge bases for the appropriate part of the value chain in production (Asheim 2002), as well as drawing essential competencies into the firm as individual projects require.

While the above literature has asked important questions pertaining to the organisation, constitution and operation of projects, I suggest that there has been a too narrow a focus on projects as forms of organisational practice, at the expense of developing more nuanced understandings of the working conditions of those experiencing the effects of the neo-liberalisation of work. With this criticism in mind, in the following section of the paper, I turn to areas of academic work for which this has been a primary concern, namely sociology and related fields such as cultural and media studies. 


\section{Project-based working in the creative industries: sociological perspectives}

For Gill and Pratt (2008), cultural and creative workers symbolise the contemporary transformations of work perhaps more than any other type of worker. As McGuigan (2010) asserts, the effects of the neo-liberalisation of work have been pervasive across the creative industries in general and they are marked by an expanding workforce comprising of freelance, casualised and project-linked persons (McRobbie 2002). Indeed the creative industries are characterised, perhaps more than any other industrial sector, by project-based work (Christopherson 2004) and in some sectors - such as film and television fragmentation and deregulation have resulted in almost universal freelance working (Davenport 2006; Saundry \& Nolan 1998; Ursell 2000). For Jones (1996), cultural and creative workers are 'exemplars' of the move away from stable notions of career to more informal, insecure and discontinuous employment.

Freelancing, precariousness and exploitation

As Gill and Pratt (2008) highlight, employment in project-based work is characterised by short tenure and constant employment uncertainty, that is to say it is precarious employment (see also: Murdock 2003; Ross 2008). Here the terms 'precarity' and 'precariousness' (see Neilson \& Rossiter 2005) are used to refer to all forms of insecure, contingent flexible work, from illegalised, casualised, temporary employment to homeworking, piecework, and freelancing. Gill and Pratt highlight how increasing numbers of workers in affluent societies are engaged in insecure, casualised or irregular labour and note that while capitalist labour has 
always been characterised by intermittency for lower-paid and lower-skilled workers, the recent departure is the addition of well-paid and high-status workers into this group of 'precarious workers', who have become subject to "structured job insecurity" (Blair et al. 2001 - 174). They highlight a number of relatively 'stable' features of this kind of work:

A preponderance of temporary, intermittent, and precarious jobs; long hours and bulimic patterns of working; the collapse or erasure of the boundaries between work and play; poor pay; high level of mobility; passionate attachment to the work and to the identify of creative labourer (e.g. artists, fashion designers); an attitudinal mind-set that is a blend of bohemianism and entrepreneurialism; informal work environments and distinctive forms of sociality; and profound experiences of insecurity and anxiety about finding work, earning enough money and 'keeping up' in rapidly changing fields. $(2008-14)$

Similarly, Hesmondhalgh and Baker (2010) identify a number of features that apply to labour in the cultural industries, including irregular work, short-term contracts, little job protection, uncertain career prospects and unequal earnings. Entwistle and Wissinger describe it as "unpredictable, erratic and precarious" making "considerable demands upon the individual in terms of their self-reliance and resourcefulness" (2006 - 782). As Dex et al. (2000) note in their study of contractual changes in the television industry, for the majority of cultural and creative workers, these demands can cause considerable stress. There is, then, a new relationship between employee and employer, where employers no longer accept responsibility for the employment and development of the workforce, but 
rather have a relationship with the employee that is transactional, contractual and short-term (du Gay et al. 1996). Risks have been passed to the workforce and away from firms (Dex et al. 2000) and individuals have a heightened level of responsibility for their individual destinies (Ekinsmyth 1999, 2002). As Storey et al. note this gives rise to the need for employees to be enterprising about making themselves enterprising, that is to say the need to develop an 'enterprising self':

...the discourse of 'enterprise positions the new type of employee as responsible for their own success and failure, and seeks to position freelance workers in particular as actors responsible for developing their own skills and associated attributes in a manner appropriate to competitive, free-market conditions. (2005 1049)

For Ross (2003), firms in the 'new economy' aim to provide work cultures that embrace openness, cooperation and self-management, but in doing so they can also produce work cultures linked to long working hours and serious erosion of the line between work and leisure. For cultural and creative workers, job gratification can come at a heavy, sacrificial cost (Ross 2008). Gill and Pratt (2008) argue that much research points to the extra-ordinarily long working hours of cultural workers, often considerably in excess of working-time agreements and exerting heavy costs on, or even prohibiting, personal relationships with friends, family and partners outside work. In their research into employment in the British film industry, for example, Blair et al. (2001) found that for a particular film crew the working day ran to a maximum of 16 hours, while a maximum working week ran to 112 hours. Gill and Pratt (2008) also note that research points to the significant disruption causes 
by 'bulimic' patterns of working, in which 'idle periods with no work can give way to periods that require intense activity, round-the-clock working, with its attendant impacts on sleep, diet, health and social life" (2008 - 17). This has led to the development of productivist critiques that focus on the politics of cultural work and emphasise the exploitive nature of capital and the demands placed on workers by the commercial imperatives of the firm. Banks (2007) for example argues that cultural workers must:

...do whatever is required to support commercial interests. It increasingly requires working longer or unsocial hours, taking on-board additional responsibilities, relocating according to company demands and certainly committing oneself to the commercial imperatives of the firm over and above non-working commitments. (Banks, 2007 - 36)

It is argued in such critiques that a cultural worker's whole life and sense of self becomes bound up with their work (Blair 2001), effectively commercialising the entire context of their life (Pongratz \& Voß 2003). Moreover, given the particular nature of cultural work, Ross argues that firms enlist "employee's freest thoughts and impulses in the service of salaried time" (2003 - 19). However, for Gill and Pratt:

Long hours and the takeover of life by labour may be dictated by punishing schedules and oppressive deadlines, and may be experienced as intensely exploitive, but they may also be the outcome of passionate engagement, creativity and self-expression... (2008 - 18) 
The experience of cultural workers, and the meanings which cultural workers gives to working practices, may then therefore not correlate with many productivist critiques. Indeed, the passionate engagement with, and attachment to, work in the creative industries means that many cultural and creative workers, as Gill and Pratt (2008) recognise, frequently make no distinction between 'work time' and 'other time', with the borders between work and life becoming more permeable or even dissolving entirely (c.f. Henninger \& Gottschall 2007). Work, as paid employment, is not therefore separated out in a clear-cut way from other domains of life (cf. Giddens 1994).

The attachment to work undoubtedly forms part of the sheer appeal and popularity of work in the creative industries (Ursell 2006). As Guile (2006) asserts, the increasing number of graduates who hold degrees in creative and cultural subjects means that the supply of people who aspire to work in this sector often exceeds demand. Moreover, Guile (2009) suggests that the massification of higher education has created a new post-degree 'vocational need' because although studying for a degree provides a grounding for new entrants to the labour market, it rarely provides an "expectation or understanding of what was required in vocational contexts" (Raffo et al. 2000 - 223). In the creative industries, this type of vocational experience is most commonly gained through undertaking unpaid activities that offer aspiring entrants opportunities to work with experienced professionals on commercial projects (Guile 2009). This leads many graduates to accept that the best way to secure an early foothold in the sector is to participate in such unpaid activities, essentially providing free labour which becomes 'masked' in the form of 
internships (Holt and Lapenta 2010). Hesmondhalgh (2010) suggests that the billions of hours of unpaid labour extracted by media companies can be seen as a 'kind of rent' (in the technical economic sense), which is offset by the considerable time needed to train and mentor a constant influx of young, inexperienced workers. However, this he argues "does not come close to matching the financial advantages gained by media companies" (2010 - 279). Such a system has resulted in many examples of 'chronic exploitation' (McGuigan 2010) of young people who are unpaid and overworked in the creative industries, as well as discrimination against those unable to undertake such unpaid work in terms of future career opportunities. However, as Hesmondhalgh (2010) argues, the situation is much more complicated than one of simple exploitation, as this 'free labour' is "simultaneously voluntarily given and unwanted, enjoyed and exploited" (Terranova $2004-74)$.

The importance of networks

Although networks have become a major analytical concept in economic geography, recent critiques have argued that the networking paradigm is inherently positive and associative (Vorley et al. 2002), and does not recognise unequal power relations and the fragility of networks and social relations (see Markusen, 2003; Grabher 2006). Indeed, for Vorley et al., this associative paradigm "fails to recognise the full heterogeneity of network practices in economic geography" (2012 - 80). Sociologists, however, have been attempting to come to terms with the tensions between heterogeneous social networks and economic transactions for some time, from Grannovetter's (1973) seminal work on 'the strength of weak 
ties' and their impact on the diffusion of influence, information and mobility opportunity, to Coleman's (1990) work on social capital and the productive capacities of social networks. More recently, paralleling the development of production network approaches in economic geography that have attempted to grapple with the complexities of the structure, nature and form of organisational networks in the creative industries (see Johns 2006), sociologists and cultural media scholars have also been grappling with the heterogeneous and political nature of social networks in these industries.

In the creative industries, social mechanisms are considered to assume an important role in the allocation of work (Baumann 2002) due to the high levels of uncertainty prevailing regarding employment. As Hesmondhalgh and Baker (2010) suggest, due to the short-term nature of most contracts in project-based creative industries, "job seeking is relentless, even during times of employment" (2010 12). Therefore, for freelancers, the development of a good network of personal contacts is vital in finding work, as when work is scarce the quality of these networks may determine whether a freelance career continues or ends (Randle \& Culkin 2009). In the creative industries, there is a wide appreciation that "contacts that eventually lead to contracts rely on sociability" (Hesmondhalgh \& Baker 2010 13). Networking is then the 'emblematic practice' in projects (Wittel 2001). As well as professional networks and communities of practice revolving around firms, projects also involve personal networks that "symptomatically efface the distinction between private and business" (Grabher 2004 - 105). In "an economy of favours" (Ursell 2000 - 822) it is often personal networks, rather than formal firm contractual networks, that provide the basic social infrastructure for putting together a project 
team. For example, in her study of new media, Christopherson highlights how media workers "overwhelmingly depend on personal networks to make employment matches" (2002 - 2011). Similar findings emerge from Blair et al's (2001) study of the British film industry, in which they found that the majority of workers hear about employment opportunities from someone they had worked with before; and from Skilton's (2008) study of the Hollywood film industry, in which he finds that breaking into elite Hollywood projects is aided by familiarity through work relationships. As Townley et al. (2009) note, such studies emphasise the importance of social networks and network ties that condition access and referrals to projects (see also Perry-Smith \& Shalley 2003).

Christopherson also notes that once employed, new-media workers "spend a considerable portion of their work-week in activities related to maintaining their employability" (2002 - 2011). She identifies that for some workers, as much as 20 per cent of their time was spent looking for new work. However, such quantitative measures perhaps ignore or underestimate time that is spent networking in industries in which workers must fashion a 'useful self' and project themselves through strenuous self-activity (McRobbie 2002) given "frantic networking is a salient feature of such working life" (McGuigan 2010 - 333). This self-activity includes scanning of the markets for future employment opportunities, making and maintaining contact to potential buyers of labour, actively selling one's self for future projects; as well as enhancing one's employability by updating and developing skills (Haunschild \& Eikhof 2009). Blair (2009) employs the term 'active networking' to describe how networking is "a conscious, on-going and active process in which actors knowingly and instrumentally engage" (Blair 2009 - 116). 
She suggests that, in active networking, individuals consciously act to make and maintain contacts with other individuals and groups based on the assumption that a variety of forms of information or opportunities for work will be more readily available as a consequence:

Freelancers operating in this manner build up a large number of contacts on whom they draw for information and for job opportunities. The reduction of employment uncertainty, rather than taking place through a fixed set of working relationships, is more dependent upon a wide net of contacts in positions either to recommend, set up a job or offer a job directly (Blair, 2009 - 131)

Moreover, sociality and networking are also key in spreading reputation. As Zafirau (2008) argues, reputation is an important feature in the interactional contexts of work in the creative industries. This is due to the way it acts as a stabilising feature of an otherwise uncertain business, helping to make contacts, facilitating the development of trust within networks, and marking competency. As well as 'active' networking, workers in the creative industries also perform 'reputation work' in order to enhance their 'networked reputation' (Glückler \& Armbrüster 2003; Glückler, 2005; Glückler 2007), a situation where new contacts learn about each other's reputation through joint trusted contacts within their social network. Wordof-mouth recommendations about competency are of particular importance. In his study of the Hollywood talent industry, for example, Zafirau finds that maintaining a favourable reputation is "not only an object of necessity, but a fundamental piece of the day to day work that Hollywood agents and managers do" (2008 - 102). 'Active networking' and 'reputation work' can then both been seen as part the "wider 
intensification of the self-commodification processes by which each individual seeks to improve his/her chances of attracting gainful employment" (Ursell 2000 807).

However, this perhaps paints an over-simplified view of networks. It is important to note that networking may not always be seen as 'compulsory sociality' (see Gill \& Pratt 2008; Gregg 2008) required to survive in a field. It may also at times be seen as pleasurable 'hanging out' (see Pratt 2006) with friends and contacts. Moreover, for Antcliff et al. (2007) to consider networks as simply assemblages of contacts used to gain individual advantage is to fail to take account of the social and organisational settings in which these networks are embedded. It is also important to consider, they argue, that workers also rely on their networks to foster collaboration, trust and co-operation, and to provide support, resources and solutions to problems (see for example Kennedy, 2010, on web designers). Networks are also sources of social identity and continuity (Staber 2004); play an important role in creating a sense of community within fragmented industries (Scott 2004; cf. Davenport 2006); and can play a key role in the defence of workers terms and conditions (Saundry et al. 2007).

Working practices in project-based creative industries can be both individual and collective. The institutional structures in which these networks are embedded determine the ways in which interpersonal networks are built and the purposes to which they are utilised within labour markets, creating opportunities, but also posing significant constraints (Blair et al. 2003). As Christopherson (2002) notes, the social-network basis for job matching in industries such as the new media may 
be responsible for inequalities in pay and opportunity. For example, Christopherson points to the fact that while many men can rely on the personal 'old boys' network to insure continuous employment, women are paid less than men and are near the bottom of occupational hierarchies, with few in positions of power or control (see for example Beale 1999; Gill 2002).Thus women are dependent on a wider range of sources of job information. Personal networks, she argues, are "inherently exclusive rather than inclusive, so create nontransparent hierarchies that potentially hamper professional mobility" (2002 - 2012) and so can make new entry into project ecologies very difficult (see for example Johns 2010).

\section{Concluding discussion}

This article has provided a brief overview of current work on the economic geography of projects. Within this literature there has been the development of some very important insights into project-based economic organisation, amongst the most significant of which is the development of a non-essentialist perspective from which projects are viewed as being dependent on time and place, and upon localities, institutions and networks (see especially Grabher 2001b, 2002a). However, I have argued that despite such advances, there remains a limitation to this literature, especially in approaches concerned with organisational networks such as work on the political economy of production networks. This limitation is too narrow a focus on projects as forms of economic organisation, and on meso-level analysis of networks at an inter- and intra-organisational level, at the expense of developing understandings of work in project-based industries and its associated micro-level social, cultural and political practices. 
Following Christopherson (2002) we can identify three forces shaping work lives in project-based creative and media industries. First, cultural and creative workers need to maintain a close connection with, and continually obtain information on, their employers and/or customers. Second, they have an expectation of 'precarity', high levels of job turnover, and mobility from project to project and from employer to employer. Finally, they have a relative reliance on social networks to obtain employment and to build a career. Ross notes that while a few cultural workers will thrive under these conditions, most will exist "in a limbo of uncertainty, juggling their options, massaging their contacts, never knowing where their next project or source of income is coming from" (2008 - 36). The resultant cycle of 'feast and famine', Ross argues, is familiar to anyone whose livelihood folds into the creative economy. The extent to which individuals are able to cope with uncertainty will influence the viability of cultural and creative workforces to sustain their potential and quality of the product in a wide range of project-based creative industries (Dex et al. 2000). However, the situation is more complex than some productivist critiques suggest. Cultural work is invariably more than a job; it becomes a labour of love. Thus there exists an intimate connection between the process of subjectification and subjection (Ursell 2000).

In light of this critique, I argue for the incorporation of sociological perspectives into our analyses of projects, in order to address the lack of attention to the sociological, political and cultural issues of work. Such an approach, I suggest, can contribute to the economic geography of projects in three crucial ways. First, rather than considering the economic structure of a particular 
organisation or industry, the approach places emphasis on the embodied agency of workers in project-based industries. It that sense it is concerned with the people involved in the 'daily practices of work' (Ettlinger 2003) that are often uncritically subsumed into inter-firm networks. Secondly, the approach challenges the centrality of the firm in economic geography, in its focus on the social networks that are so crucial in project-based industries increasingly characterised by freelancing and precarity. Empirical work has demonstrated that individuals may form networks within and outside firms that can either advance the interests of their employers (see for example Amin and Cohendet 1999) or prioritise personal interests over those of their employers (see for example Christopherson 2002). As Boggs and Rantisi (2003: 112) emphasise, "the logics that inform workplace practices cannot solely be understood in narrow economic terms or in terms of one single rationality, and accordingly, cannot be unconsciously equated or conflated with those of the firm". As Yeung (2005) argues that there is a need for a relational conception of the firm as social networks in which actors are embedded in on-going power relations and discursive processes. Finally, and associated with the above, the approach encourages fine-grained, micro-level analysis of economic activity that uncovers the practices that form, maintain, and sometime inhibit or break, social networks between individuals engaged in project-based work.

While each of these three 'shifts' - from structure to agency, from firm to social networks, and from macro/meso to micro-level analysis - have been outlined in a theoretical sense in the body of literature on the relational turn in economic geography which emerged in the early 2000s (see in particular Boggs and Rantisi 2003), the framework outlined here offers an empirical approach to incorporating 
these shifts into work in economic geography on projects. Doing so successfully is central to developing an understanding of project-based working that is sensitive to the geographical scales across which actors and their networks operate (see

Dicken et al. 2001). In allowing for very fine-grained micro-level analyses of the practices of project work and their associated social and cultural practices and politics, such a framework for analysis is one which would usefully complement and extend existing meso-level work concerned with production networks and the social aspects of production, not only across the creative industries, but across project-based industries more widely. Some examples of such practices highlighted in this paper include changes in labour conditions that see the rise of precarious freelance temporary and free labour, and the associated heterogeneous and political practices of social networking, including active networking and the development of networked reputation, through which workers in project-based industries reduce uncertainty around employment. Drawing on such a framework then, economic geographers have an important role to play in providing more nuanced accounts and critiques of the neo-liberalisation of work across projectbased industries.

\section{Acknowledgements}

I am very grateful to two anonymous referees for their constructive reviews, as well as to the section editor, James Faulconbridge, for his suggestions for bringing the argument presented in this paper into sharper focus. The paper is much stronger for their input. I would also like to thank Phil Hubbard and Michael Hoyler for their helpful comments on earlier versions of this paper. Finally, I wish to 
acknowledge funding from the Department of Geography, Loughborough University, towards the $\mathrm{PhD}$ research that informs this paper.

\section{References}

Amin, A. and Cohendet, P. (1999). Learning and adaption in decentralized business networks. Environment and Planning D: Society and Space, 17, pp. $87-104$

Antcliff, V., Saundry, R., and Stuart, M. (2007). Networks and social capital in the UK television industry: the weakness of weak ties. Human Relations 60 (2), pp.371-393.

Asheim, B. T. (2002). Temporary organizations and spatial embeddedness of learning and knowledge creation. Geografiska Annaler 84 B (2), pp. 111124.

Banks, M. (2007). The Politics of Cultural Work. Basingstoke: Palgrave MacMillan.

Banks, M. and Hesmondhalgh, D. (2009). Looking for work in creative industries policy. International Journal of Cultural Policy. 15 (4), pp. 415-430.

Bathelt, H. (2002). The re-emergence of a media industry cluster in Leipzig. European Planning Studies. 10 (5), pp. 583-611 
Bathelt, H. (2005). Cluster relations in the media industry: exploring the 'distanced neighbour' paradox in Leipzig. Regional Studies. 39, pp. 105-127.

Bathelt, H. and Glückler, J. (2003). Toward a relational economic geography. Journal of Economic Geography. 3 pp. 117-144.

Baumann, A. (2002). Informal labour market governance: the case of British and German media production industries. Work, Employment and Society. 16 (1), pp. 27-46.

Beale, A. (1999). From 'Sophie's Choice' to consumer choice: framing gender in cultural policy. Media, Culture \& Society. 21, pp. 435-458.

Blair, H. (2001). "You're only as good as your last job": the labour process and labour market in the British Film Industry. Work, Employment and Society. 15 (1) pp. 149-169.

Blair, H. (2009). Active networking: action, social structure and the process of networking. In McKinlay, A. and Smith, C., (eds.) Creative Labour: Working in the Creative Industries. Basingstoke: Palgrave Macmillan.

Blair, H., Culkin, N. and Randle, K. (2003). From London to Los Angeles: a comparison of local labour market processes in the US and UK film industries. The International Journal of Human Resource Management. 14 (4), pp. 619- 633. 
Blair, H., Grey, S. and Randle, K. (2001). Working in film: employment in a project based industry. Personnel Review. 30 (2), pp. 170-185.

Boggs, J. S. And Rantisi, N. M. (2003). The 'relational turn' in economic geography. Journal of Economic Geography, 3, pp. 109-116.

Bourdieu, P. (1984). Distinction: A Social Critique of the Judgment of Taste. London: Routledge and Kegan Paul.

Brown, J. S. and Duguid, P. (2001). Organizational learning and communities-ofpractice: toward a unified view of working, learning, and innovation. Organization Science, 2, pp. 40-57.

Christopherson, S. (2002). Project work in context: regulatory change and the new geography of media. Environment and Planning A. 34, pp. 2003-2015.

Christopherson, S. (2004). The divergent worlds of new media: how policy shapes work in the creative economy. Review of Policy Research. 21 (4) pp. $543-$ 558.

Christopherson, S. and Storper, M. (1989). The effects of flexible specialisation on industrial politics and the labor market: the motion picture industry. Industrial and Labor Relations Review. 42 (3), pp. 331-347. 
Coe, N.M. (2001). A hybrid agglomeration? The development of a satelliteMarshallian industrial district in Vancouver's film industry. Urban Studies. 38 (10), pp. 1753-1775.

Coe, N.M. and Johns, J. (2003). Beyond production clusters: towards a critical political economy of networks in the film and television industries. In Power, D. and Scott, A.J., (eds.) Cultural Industries and the Production of Culture. London: Routledge.

Cole, A. (2008). Distant neighbours: the new geography of animated film production in Europe. Regional Studies. 42 (6), pp. 891-904.

Crewe, L. (1996). Material culture: embedded firms, organizational networks and the local economic development of a fashion quarter. Regional Studies. 30, pp. 257-272.

Davenport, J. (2006). UK film companies: project-based organisations lacking entrepreneurship and innovativeness? Creativity and Innovation Management.15 (3), pp. 250-257.

DeFillippi, R.J. and Arthur, M. B. (1998) Paradox in project-based enterprise: the case of film making. California Management Review. 40 (2), pp. 125-139. 
Dex, S., Willis, J., Peterson, R. and Sheppard, E. (2000). Freelance workers and contract uncertainty: the effects of contractual changes in the television industry. Work, Employment \& Society. 14 (2), pp. 283-305.

Dicken, P., Kelly, P. F., Olds, K. and Yeung, H. W. (2001) Chains and networks, territories and scales: towards a relational framework for analysing the global economy. Global Networks, 1 (2), pp. 345-363

Du Gay, P., Salaman, G. and Rees, B. (1996). The conduct of management and the management of conduct: contemporary managerial discourse and the constitution of the 'competent' manager. Journal of Management Studies. 33 pp. 263-282.

Eberts, D. and Norcliffe, G. (1998). New forms of artisanal production in Toronto's computer animation industry. Geographische Zeitschrift. 86 (2), pp. 120133.

Ekinsmyth, C. (1999). Professional workers in a risk society. Transactions of the Institute of British Geographers. 24 (3), pp. 353-366.

Ekinsmyth, C. (2002). Project organization, embeddedness and risk in magazine publishing. Regional Studies. 36 (3), pp. 229-243. 
Ekstedt, E., Lundin, R., Söderholm, A. and Wirdenius, H. (1999). Neo-Industrial Organising: Renewal by Action and Knowledge Formation in a ProjectIntensive Economy. London: Routledge.

Entwistle, J. and Wissenger, E. (2006). Keeping up appearances: aesthetic labour in the fashion modelling industries of London and New York. The Sociological Review. 54 (4), pp. $774-794$.

Ettlinger, N. (2003). Cultural economic geography and a relational and microspace approach to trusts, rationalities, networks and change in collaborative workplaces. Journal of Economic Geography. 3 (2), 145-171.

Gann, D. M. and Salter, A. J. (2000). Innovation in project-based, serviceenhanced firms: the construction of complex products and systems. Research Policy. 29, pp. 955-972.

Giddens, A. (1994). Beyond left and right: the future of radical politics. Cambridge: Polity Press.

Gill, R. (2002). Cool, creative and egalitarian? Exploring gender in project-based new media work in Europe. Information, Communication and Society. 5 (1), pp. 70-89. 
Gill, R. and Pratt, A. C (2008). In the social factory? Immaterial labour, precariousness and cultural work. Theory, Culture and Society. 25 (7-8), pp. $1-30$.

Glückler, J. (2005). Making embeddedness work: social practice institutions in foreign consulting markets. Environment and Planning A. 37, pp. 1727 1750.

Glückler, J. (2007). Geography of reputation: the city as locus of business opportunity. Regional Studies. 41 (7), pp. 949-961.

Glückler, J. and Armbrüster, T. (2003). Bridging uncertainty in management consulting: the mechanisms of trust and networked reputation. Organization Studies. 24, pp. 269-297.

Grabher, G. (2001a). Ecologies of creativity: the village, the group, and the heterarchic organisation of the British advertising industry. Environment and Planning A. 33 (2) pp. 351-374.

Grabher, G. (2001b). Locating economic action: projects, networks, localities, institutions. Environment and Planning A. 33 (8) pp. 1329-1331.

Grabher, G. (2002a). Cool projects, boring institutions: temporary collaboration in social context. Regional Studies. 36, 205-214. 
Grabher, G. (2002b). Fragile sector, robust practice: project ecologies in new media. Environment and Planning A. 34, pp. 1911-1926.

Grabher, G. (2004). Learning in projects, remembering in networks? Communality, sociality, and connectivity in project ecologies. European Urban and Regional Studies. 11 (2), pp. 103-123.

Gregg, M. (2008). Testing the friendship: feminism and the limits of online social networks. Feminist Media Studies. 8 (2) pp. 197-223.

Guile, D. (2006). Access, learning and development in the creative and cultural sectors: from 'creative apprenticeship' to 'being apprenticed'. Journal of Education and Work. 19 (5), pp. 433-453.

Guile, D. (2009). Conceptualizing the transition from education to work as vocational practice: lessons from the UK's creative and cultural sector. British Educational Research Journal. 35 (5), pp. 761-779.

Haunschild, A. and Eikhof, D. R. (2009). Bringing creativity to market: actors as self-employed employees. In McKinlay, A. and Smith, C., (eds.) Creative Labour: Working in the Creative Industries. Basingstoke: Palgrave Macmillan. 
Henninger, A. and Gottschall, K. (2007). Freelancers in Germany's old and new media industry: beyond standard patterns and work and life. Critical Sociology. 33, pp. 43-71.

Hesmondhalgh, D. (2010). User-generated content, free-labour and the cultural industries. Ephemera. 10 (3/4), pp. 267-284.

Hesmondhalgh, D. and Baker, S. (2010). 'A very complicated version of freedom': conditions and experiences of creative labour in three cultural industries. Poetics. 38 pp. 4-20.

Hobday, M. (2000). The project-based organisation: an ideal form for managing complex products and systems. Research Policy. 29, pp.871-893.

Holt, F. and Lapenta, F. (2010). Introduction: autonomy and creative labour. Journal for Cultural Research. 14 (3), pp. 223-229

Johns, J. (2006). Video games production networks: value capture, power relations and embeddedness. Journal of Economic Geography. 6 (2), pp. 151-180

Johns, J. (2010). Manchester's film and television industry: project ecologies and network hierarchies. Urban Studies. 47 (5), pp. 1059-1077.

Jones, C. (1996) Careers in project networks: the case of the film industry. In Arthur, M. B. and Rousseau, D. M., (eds.) The Boundaryless Career: A New 
Employment Principle for a New Organizational Era. Oxford: Oxford University Press.

Kennedy, H. (2010). Net work: the professionalization of web design. Media, Culture \& Society. 32 (2), pp. 187-203.

Koskinen, K. U., Pihlanto, P., and Varharanta, H. (2003). Tacit knowledge acquisition and sharing in a project work context. International Journal of Project Management. 21, pp. 281-290.

Lorenzen, M. and Frederiksen, L. (2005). The management of projects and product experimentation: examples from the music industry. European Management Review. 2 (3), pp. 198-211.

Lundin, R. A. and Midler, C. (1998). Evolution of projects as empirical trend and theoretical focus. In Lundin, R. A. and Midler, C., (eds.) Projects as Arenas for Renewal and Learning Processes. Norwell: Kluwer Academic, pp. 1-9.

Lundin, R. A. and Söderholm, A. (1995) A theory of the temporary organization. Scandinavian Journal of Management. 11, pp. 437-455.

Maskell, P. (2001). The firm in economic geography. Economic Geography. 77 (4) pp. 329-344. 
McDowell, L. (1997). Capital Culture: Gender at Work in the City. Oxford: Blackwell.

McGuigan, J. (2010). Creative labour, cultural work and individualisation. International Journal of Cultural Policy. 16 (3), pp. 323-335.

McRobbie, A. (2002). Clubs to companies: notes on the decline of political culture in speeded up creative worlds. Cultural Studies. 16 (4), pp. 516-531.

Meyerson, D., Weick, K. E., and Kramer, R .M. (1996). Swift trust and temporary groups. In Kramer, R. M. and Tyler, T. R., (eds.) Trust in Organizations: Frontiers of Theory and Research. Thousand Oaks: Sage.

Midler, C. (1995). 'Projectification' of the firm: the Renault case. Scandinavian Journal of Management. 11, pp. 363-375.

Murdock, G. (2003). Back to work: cultural labour in altered times. In Beck, A., (ed.) Cultural Work: Understanding the Cultural Industries. London: Routledge

Neilson, B. and Rossiter, N. (2005). From precarity to precariousness and back again: labour, life and unstable networks. Fiberculture. 5, no pagination.

Norcliffe, G. and Rendace, O (2003). New geographies of comic book production in North America: the new artisan, distancing, and the periodic social economy. Economic Geography. 79 (3), pp. 241-263. 
Perry-Smith, J. and Shalley, C. (2003). The social side of creativity: a static and dynamic social network perspective. Academy of Management Review. 28 pp. 89-106.

Pongratz, H. G. and Voß, G. G. (2003). From employee to 'entreployee': towards a 'self-entrepreneurial' work force? Concepts and Transformations. 8 (3), pp. 239-254.

Power, D. and Hallencreutz, D. (2002). Profiting from creativity? The music industry in Stockholm, Sweden and Kingston, Jamaica. Environment and Planning A. 34 (10), pp. 1833-1854.

Power, D. and Jansson, J. (2004). The emergence of a post-industrial music economy? Music and ICT synergies in Stockholm, Sweden. Geoforum. 35 pp. $425-439$.

Pratt, A. C. (2000). New media, the new economy and new spaces. Geoforum. 31, pp. $425-436$.

Pratt, A. C. (2002) Hot jobs in cool places. The material cultures of new media product spaces: the case of south of the market, San Francisco. Information, Communication and Society. 5 (1), pp. 27-50. 
Pratt, A. C. (2006). Advertising and creativity, a governance approach a case study of creative agencies in London. Environment and Planning A. 38 (10), pp. 1883-1899.

Raffo, C., O'Connor, J., Lovatt, A. and Banks, M. (2000). Attitudes to formal business training amongst entrepreneurs in the cultural industries: situated business learning through 'doing it with others'. Journal of Education and Work. 13 (2), pp. 215-230.

Randle, K. and Culkin, N. (2009). Getting in and getting on in Hollywood: freelance careers in an uncertain industry. In McKinlay, A. and Smith, C., (eds.) Creative Labour: Working in the Creative Industries. Basingstoke: Palgrave Macmillan.

Ross, A. (2003). No-Collar: The Human Workplace and its Hidden Costs. Philadelphia: Temple University Press.

Ross, A. (2008). The new geography of work: power to the precarious? Theory, Culture and Society. 25 (7-8), pp. 31-49.

Saundry, R., Antcliff, V. and Stuart, M. (2007). 'It's more than who you know' networks and trade unions in the audio-visual industries. Human Resource Management Journal. 16 (4), pp. 376-392. 
Saundry, R. and Nolan, P. (1998). Regulatory change and performance in TV production. Media, Culture \& Society. 20, pp. 409-426.

Scott, A. J. (2004). The other Hollywood: the organisational and geographic bases of television program production. Media, Culture \& Society. 26 (2), pp. 183205.

Skilton, P. (2008). Similarity, familiarity and access to elite work in Hollywood. Human Relations. 61 pp. 1743-1773.

Staber, U. (2004). Networking beyond organisational boundaries: the case of project organizations. Creativity and Innovation Management. 13 (1), pp. 3040.

Storey, J., Salaman, G. and Platman, K. (2005). Living with enterprise in an enterprise economy: freelance and contract workers in the media. Human Relations. 58 (8), pp. 1033-1054.

Storper M. and Venables A. J. (2004). Buzz: face-to-face contact and the urban economy. Journal of Economic Geography. 4, pp. 351-70.

Taylor, M. and Asheim, B. (2001). The concept of the firm in economic geography. Economic Geography. 77 (4) pp. 315-328. 
Terranova, T. (2004). Network Culture: Politics of the Information Age. London: Pluto Press.

Townley, B., Beech, N. and McKinlay, A. (2009). Managing in the creative industries: managing the motley crew. Human Relations. 62 (7), pp. 939962.

Turok, I. (2003) "Cities, clusters and creative industries: the case of film and television in Scotland" European Planning Studies. 11 (5) pp. 549-565

Ursell, G. (2000). Television production: issues of exploitation, commodification and subjectivity in UK television labour markets. Media, Culture and Society. 22 pp. 805-825.

Ursell, G. (2006). Working in the media. In Hesmondhalgh, D., (ed.) Media Production. Maidstone: Open University Press.

von Bernuth, C. and Bathelt, H. (2007). The organizational paradox in advertising and the reconfiguration of project cooperation. Geoforum. 38, pp. 545-557.

Vorley, T., Mould, O. and Courtney, R. (2012). My networking is not working! Conceptualizing the latent and dysfunctional dimensions of the network paradigm. Economic Geography. 88 (1) pp. 77-96 
Watson, A. (2008). Global music city: knowledge and geographical proximity in London's recorded music industry. Area. 40 (1) pp. 12-23.

Wittel, A. (2001). Toward a network sociality. Theory, Culture and Society. 18 (6) pp. 51-76.

Yeung, H.W. (2003). Practicing new economic geographies: a methodological examination. Annals of the Association of American Geographers. 93 (2) pp. 442-462.

Yeung, H. W. (2005). The firm as social networks: an organizational perspective. Growth and Change, 36 (3) pp. 307-328.

Yoon, H. and Malecki, E.J. (2009). Cartoon planet: worlds of production and global production networks in the animation industry. Industrial and Corporate Change. 19 (1) pp. 239-271.

Zafirau, S. (2008). Reputation work in selling film and television: life in the Hollywood talent industry. Qualitative Sociology. 31, pp. 99-127. 